\title{
Education In Era 4.0 Based On Local Wisdom: Existence Of Value And Technology
}

\author{
Irfai Fathurohman ${ }^{1}$, Mohammad Kanzunnudin ${ }^{2}$, Aris Tamarudin ${ }^{3}$, Riyan Dwi Cahyaningsih ${ }^{4}$ \\ \{irfai.fathurohman@umk.ac.id ${ }^{1}$, moh.kanzunnudin@umk.ac.id² aristamarudinsabaku@gmail.com³ \\ riyan.dwicahyaningsih1@gmail.com ${ }^{4}$ \} \\ ${ }^{1,2}$ Lecturer in Program Studi Pendidikan Bahasa dan Sastra Indonesia, Universitas Muria Kudus, \\ Indonesia \\ ${ }^{3}$ Teacher Matematika SMA 1 Bae Kudus, Indonesia \\ ${ }^{4}$ College student Pascasarjana Universitas Negeri Semarang, Indonesia \\ Scopus Author ID: $57198432046^{1} ; 57198448025^{2}$
}

\begin{abstract}
Education as the spearhead in changing times, the superiority of the work ethic, and the building elements that cannot be ruled out. As a basis in influencing various events of educational life, it is endeavored to have distinctive features such as bringing up local wisdom in learning so that the content of elements in life can be applied in learning. The need for technology as a medium and educational intermediary is a space that can be utilized to provide convenience in education so that the values that exist in local wisdom can be understood more easily through the use of technology. This article discusses the role and application of education in the 4.0 era that uses a local advantage in the form of local wisdom as a specialty that has values in life. The development of technology needs to be addressed properly and quickly so that students in learning and getting to know the environment can preserve it well, things they don't know yet.
\end{abstract}

Keywords: Education, era 4.0, local wisdom, values, and technology.

\section{Introduction}

Education has now begun to shift from conventional learning which not only uses books as the only source of learning but has also applied the latest learning resources in accordance with the circumstances in the field. This situation is also supported by the existence of online learning resources and various addresses on the internet network. The speed of students in accessing learning resources like this needs to be responded positively because of mutual learning from students for students, students for teachers, and students for the development of mindset to be critical and active in exploring information in cyberspace and the real world. Good education, that is, education that is open in nature, does not only limit a certain theme, but also includes every event that is present in life so that the impact of education can be applied directly in social life. [1] Talking about the education paradigm, we can conclude how important it is to get an education in life. Because through education a person can develop knowledge, insight, values and character even as an effort to inherit culture in addition to being broader if you want to assess the quality of a nation can be seen from the quality of education in the country. [2] the era of the industrial revolution 4.0 that changed the world with a touch of digital technology forced the education sector to adjust itself so as not to lag behind.

As a container that holds life, society is the final impact in the application of education so that one of the indicators that determines the success of education is the quality of society that 
has been tested in addressing the life of something with the ideas, actions, and products produced. As a container that holds life, society is the final impact in the application of education so that one of the indicators that determines the success of education is the quality of society that has been tested in addressing the life of something with ideas, actions, and products produced. Local wisdom is one of the characteristics and identities that exist in social life so that it can be a differentiator between one region or region with one another. One of the identity or identity of a nation can be known from the local wisdom in it. [3] The values of local wisdom today have been abandoned. Along with advances in information technology as a result of the unstoppable flow of globalization and the weakness of the nation's filtering system against antidotes of negative impacts.

Values that exist in local wisdom such as the value of cooperation, mutual cooperation, respect, discipline, love of the motherland, polite language, and so on can be applied in local education have an impact on the characteristics of students who later can have a positive attitude towards the environment and can get to know deeper about the environment. Students who are able to understand and apply the value of local wisdom in life naturally preserve and uphold positive norms that have an impact on society in general. [4] natural wisdom is the values that apply in a society. Values that are believed to be true and become a reference in daily behavior by the local community so that if properly implemented the awareness to protect the environment will be high. [5] cultural values that have developed in people's lives lately experienced degradation and began to be forgotten in social life along with the times. But on the other hand, local cultural values which are a legacy of the past in some regions are very suitable to be developed in the face of the current era of globalization. [6] Local wisdom is formed as the cultural superiority of the local community and geographical conditions in the broadest sense. Local wisdom is a product of the culture of the past that deserves to be constantly held on to life. Although local value, but the value contained therein is considered to be very universal. [7] In the anthropological conception, custom is understood as a habit that has been passed down from generation to generation by members of the community and functions to organize social relations for the creation and maintenance of functional relations between communities.

Spaces that clearly become the material or core of learning, namely national identity and culture that can continuously be taught to students through daily learning. Through material clarity by synergizing with the culture in it, of course, these spaces can be applied wisely. As a technology that puts forward a learning media that is fast and easily accessible to students, the technology can contain a variety of local wisdom values that can be applied in education. The role and function of technology needs to be responded positively through the content or content of technology that includes local wisdom as one part of culture. [8] in the era of reform and regional autonomy has provided space and opportunities for each region to develop and maintain culture and develop the values of local wisdom and cultural history, as long as it does not conflict with the basic principles of democracy which provides a mechanism for the people's sovereignty. [9] Local wisdom is an embodiment of the implementation of articulation and manifestation as well as traditional forms of knowledge understood by humans or communities interacting with the surrounding nature.

Education in the era of 4.0 is more environmentally friendly, easily accessible, and can be done or studied in various places, no longer dependent on the place and time, and can be clearly known events in various places for the benefit of all groups. Actions that are considered to be still conventional namely education focused on one material are no longer appropriate to be taught in the current era, because ideal learning is able to apply various elements of life in it. [10] The Industrial Revolution Era 4.0 (hereinafter: Era 4.0) had not a 
simple impact. It affects all aspects of human life. Included in this case is education. This era is marked by the increasingly central role of cyber technology in human life. So do not be surprised if in the world of education the term "Education 4.0" appears.

Based on the problems that have been described, this article examines the role and application of education in the 4.0 era which uses a local advantage in the form of local wisdom as a specialty that has values in life. The development of technology needs to be addressed properly and quickly so that students in learning and getting to know the environment can preserve it well, things they don't know yet.

\section{Method}

This research uses descriptive qualitative method. The research data was obtained from textbooks used in learning at SMA 1 Bae Kudus. The source of the research data was obtained from articles and papers related to the research. Data collection techniques using observation, interviews, and documentation. Observations and interviews were conducted with teachers and students in SMA 1 Bae Districts Kudus. Documentation is obtained through learning outcomes and student learning activities during the school year 2018/2019. Data analysis uses Miles and Huberman's theory [11] namely data reduction, data presentation, and conclusion drawing. Data analysis in this study was carried out in stages so that valid and credible data analysis was obtained.

\section{Results and Discussion}

\section{a. The Role and Application of Education in the 4.0 era based on Local Wisdom}

Based on the results of research conducted at SMA 1 Bae Districts Kudus, learning patterns have put forward learning in the 4.0 era which has synergized the role of technology in learning. The textbook used has referred to BSE (Buku Sekolah Elektronik) so students are easy to access examples, materials, and learning applications. The teacher as an educator has given examples and applications according to the steps of using the available text books so students know the functions and steps of learning to use the textbooks. The following is presented regarding the textbooks of the subjects used in learning in SMA 1 Bae Kudus, Indonesia.

Table 1. Subject Textbooks in SMA 1 Bae Kudus, Indonesia.

\begin{tabular}{|c|c|c|c|}
\hline \multirow{2}{*}{ Book Type } & \multirow[t]{2}{*}{ Subjects } & \multicolumn{2}{|c|}{ Accessed } \\
\hline & & Electronic & Conventional \\
\hline Textbook & Mathematics & $\checkmark$ & - \\
\hline Textbook & Indonesian Language & $\vee$ & - \\
\hline Textbook & English Language & $\vee$ & - \\
\hline Textbook & Islamic Religious Education and Character & $\vee$ & - \\
\hline Textbook & Craft and Entrepreneurship & $\vee$ & - \\
\hline Textbook & Biology & $\vee$ & - \\
\hline Textbook & Sports physical Education and health & $\vee$ & - \\
\hline Textbook & Indonesian History & $\vee$ & - \\
\hline Textbook & Pancasila and civic education & $\vee$ & - \\
\hline Textbook & The economy & $\vee$ & - \\
\hline Textbook & Art and culture & $\vee$ & - \\
\hline Total & 11 Subjects & 11 & $\mathbf{0}$ \\
\hline
\end{tabular}


Local wisdom as one of the cultural elements becomes an important thing that needs to be taught in education. As a characteristic and recognition of good values for student understanding, local wisdom can be applied in various subjects at the high school level with reference sources from textbooks and from other sources that support. But in its application it can be clearly seen that the source of the textbooks does not all contain the local wisdom so that it is felt that there are still not enough learning resources that support the introduction and understanding of local wisdom. [12] according to Wibowo that the function and meaning of local wisdom, namely: Functioning for the conservation and preservation of natural resources, functions for the development of human resources, functions for the development of culture and science, functions as advice, beliefs, literature and taboos. [13] wisdom is not only in the form of cultural norms and values, but also all elements of ideas, including those that have implications for technology, health care and aesthetics. Thus, local wisdom is more emphasized as the ability of a region to absorb and carry out selection and active management of the influence of foreign or foreign cultures, so that new forms of creation are not found in other regions.

The following is table 2 which explains the types of textbooks which contain and do not contain local wisdom.

Table 2. Types of Textbooks in Subjects SMA 1 Bae Kudus, Indonesia.

\begin{tabular}{|c|c|c|c|}
\hline \multirow[t]{2}{*}{ Book Type } & \multirow[t]{2}{*}{ Subjects } & \multicolumn{2}{|c|}{ Local wisdom } \\
\hline & & $\begin{array}{l}\text { There } \\
\text { is }\end{array}$ & $\begin{array}{l}\begin{array}{l}\text { Not } \\
\text { available }\end{array} \\
\end{array}$ \\
\hline Textbook & Mathematics & $\mathrm{V}$ & - \\
\hline Textbook & Indonesian Language & - & - \\
\hline Textbook & English Language & - & - \\
\hline Textbook & Islamic Religious Education and Character & - & - \\
\hline Textbook & Craft and Entrepreneurship & - & - \\
\hline Textbook & Biology & - & - \\
\hline Textbook & Sports physical Education and health & - & - \\
\hline Textbook & Indonesian History & - & - \\
\hline Textbook & Pancasila and civic education & - & - \\
\hline Textbook & The economy & - & - \\
\hline Textbook & Art and culture & - & - \\
\hline Total & 11 Subjects & 1 & 10 \\
\hline
\end{tabular}


Based on the needs and application of local wisdom, the educational model needed is in accordance with the characteristics of the region that puts forward aspects and needs of the region to be truly understood by students in learning. Textbooks and learning resources that support students' understanding of local wisdom need to be supported with an introduction from the beginning of learning so that students are sensitive to the surrounding environment. Education in the 4.0 era that supports the provision of learning materials needs to be synergized with local wisdom so that students can apply the material learned to the circumstances in the student environment.

\section{b. Era Student Attitudes and Characteristics Responding to Changing Era}

The attitude of students in dealing with the changing era and the present era needs to be followed by strengthening the national identity so that the technology that is growing nowadays can be responded positively and wisely. Technology needs to be followed and not made as an obstacle but rather as a medium that can facilitate students in finding information that supports learning. Some criteria that can be used as a reference in responding to changes in the era in 4.0, namely:

1) study technology and media both online and ofline.

2) Utilizing technology as needed namely to help obtain the information needed and filter incoming information.

3) Technology as one of the complementary learning tools, not as the only primary learning source, because learning resources can be obtained from anywhere that suits your needs.

4) The attitude of dependency in learning needs to be addressed properly, so that later students are able to use technology wisely.

Based on the attitude and understanding of the character of students in addressing the changing era, the attitude is always introspective and able to filter any information that is an important element to. Era 4.0 is a reformer era that presents education more efficiently, interesting, right on target, and more detailed in its presentation.

\section{Conclusion}

The role of technology in learning is unavoidable and is always closely related to the progress of the times. Education as the spearhead in the advancement of time requires careful preparation to respond to technological progress so that it is not tossed around by various information available. One of one's maturity is based on the existence of a strong provision in him like knowing the form of local wisdom around him. Local wisdom can shape a person's character to be different from others in addressing the problems of life. As humans who always learn in recognizing and understanding the values of life, local wisdom forms a person who is superior and can respect any differences and upholds positive values that place public interests above personal interests. In the era of 4.0 which focuses on the development of environmentally friendly and further enhance technological progress as the basis of life needs to be followed because technology and the times are closely linked to the advancement of education. Technology becomes more useful and appropriate if the content or message given is in accordance with the facts and needs of students. 


\section{REFERENCES}

[1] Shufa, N.K.F. Pembelajaran Berbasis Kearifan Lokal di Sekolah Dasar Sebuah Kerangka Konseptual. Vol 1(1), pp. 48-53. Inopendas Jurnal Ilmiah Pendidikan, Indonesia, (2018)

[2] Helaluddin. Redesain Kurikulum Pendidikan Tinggi Islam: Strategi dalam Menyongsong Era Revolusi Industri 4.0. Vol 8(2), pp. 258-277. Jurnal Mudarrisuna, Indonesia, (2018)

[3] Sukmayadi, T. Nilai-Nilai Kearifan Lokal dalam Pandangan Hidup Masyarakat Adat Kampung Kuta. Vol 3(1), pp. 19-29. JPK: Jurnal Pancasila dan Kewarganegaraan, Indonesia (2018)

[4] Gunawan, R., Digdoyo, E., Subarkah, A. Budaya Kearifan Lokal Dalam Tata Kelola Dan Pengembangan Lingkungan Kota. Vol 8 (2), pp. 207-214. Jurnal Sejarah dan Budaya, Indonesia (2014)

[5] Ufie, A. Mengonstruksi Nilai-nilai Kearifan Lokal (Local Wisdom) dalam Pembelajaran Muatan Lokal sebagai Upaya Memperkokoh Kohesi Sosial (Studi Deskriptif Budaya Niolilieta Masyarakat Adat Pulau Wetang Kabupaten Maluku Barat Daya, Propinsi Maluku). Vol 23(2), pp. 79-89. Jurnal Pendidikan dan Pembelajaran, Indonesia (2016)

[6] Sartini. Menggali Kearifan Lokal Nusantara Sebuah Kajian Filsafati. Vol 37(2), pp. 111-120. Jurnal Filsafat, Indonesia (2004)

[7] Naing, N., Santosa, H.R., Soemarno, I. Kearifan Lokal Tradisional Masyarakat Nelayan Pada Permukiman Mengapung di Danau Tempe Sulawesi Selatan. Vol 1(1), pp 19-26. Jurnal Local Wisdom, Indonesia. (2009)

[8] Ade, V., Affandi, I. Implementasi Nilai-Nilai Kearifan Lokal dalam Mengembangkan Keterampilan Kewarganegaraan (Studi Deskriptif Analitik pada Masyarakat Talang Mamak Kec. Rakit Kulim, Kabupaten Indragiri Hulu Provinsi Riau). Vol 25(1), pp. 7791. Jurnal Pendidikan Ilmu Sosial, Indonesia (2016)

[9] Muhaimin. Kedudukan Kearifan Lokal dalam Penataan Ruang Provinsi Bali. Vol 18(1), pp. 59-72. Jurnal Penelitian Hukum De Jure, Indonesia (2018)

[10] Priatmoko, S. Memperkuat Eksistensi Pendidikan Islam di Era 4.0. Vol 1(2), pp. 1-19. Ta'Lim: Jurnal Studi Pendidikan Islam, Indonesia (2018)

[11] Romadhoni, F. Pola Komunikasi di Kalangan Pecandu Game Let's Get Rich di Komunitas Xlite Tenggarong. Vol 5(1), pp. 235-247. Jurnal Ilmu Komunikasi, Indonesia (2017)

[12] Ibad, S. Kearifan Lokal Pemberdayaan Masyarakat dalam Pengelolaan dan Pembangunan Sumberdaya Perikanan yang Berkelanjutan (Studi Kabupaten Situbondo). Vol 8(1), pp 24-31. Samakia: Jurnal Ilmu Perikanan, Indonesia (2017)

[13] Purna, I. M. Kearifan Lokal Masyarakat Desa Mbawa dalam Mewujudkan Toleransi Beragama. Vol 1(2), pp. 261-277. Jurnal Pendidikan dan Kebudayaan, Indonesia (2016) 